\title{
4
}

\section{Plant Self-Incompatibility: Or, Self-Induction of Population Genetic Diversity}

\author{
Łukasz Wolko and Ryszard Słomski \\ Department of Biochemistry and Biotechnology, Poznań University of Life Sciences \\ Poland
}

\section{Introduction}

The purpose of pollination is fertilization and seed production. Charles Darwin initiated studies on the phenomenon of plants "...which are completely sterile with their own pollen, but are fertile with that of any other individual of the same species" (Darwin, 1878). This inability for self-pollination is defined as self-incompatibility (SI). Self-incompatible plants have genetic systems that prevent self-fertilization through the recognition and rejection of pollen expressing the same allelic specificity as that expressed in the pistils. The mechanisms of SI, by promoting the outcrossing, would have an important influence on diversification and speciation of angiosperms because effective genetic mechanism preventing inbreeding allowed flowering plants to adapt to different environmental conditions and to accelerate the pace of evolution. Currently, SI systems are distributed widely throughout angiosperm lineages and are present in approximately 19 orders, 71 families and 250 genera comprising approximately $60 \%$ of angiosperm species (Allen \& Hiscock, 2008). However, selfincompatibility systems are greatly heterogeneous and it is difficult to establish their evolutionary relationships or to determine the ancestral SI state.

\section{Self-incompatibility systems}

Two classes of SI can be distinguished: heteromorphic and homomorphic. Heteromorphic systems are characterized by morphological differences between genotypes, particularly variations in the length of the style (heterostyly). In contrast, in homomorphic systems, the S-genotype cannot be distinguished morphologically and the incompatibility response relies only no physiological mechanisms (Castric \& Verkmans, 2004).

Most of the homomorphic SI systems are controlled by a single locus (S-locus) (Hiscock \& McInnis, 2003). The S-locus should consist of, at least, two tightly linked (non-recombining) and highly polymorphic genes. The first of these genes coding pollen identity and the second is expressed in the pistil as a factor of incompatible pollen recognition. In addition to these primary male and female determinants, many other genes, not linked to the S-locus, are involved in SI functions. These additional factors play some role in pollen tube rejection after the first step of incompatibility recognition (McClure \& Franklin-Tong, 2006; Kubo et al., 2010).

In SI plants, pistil tissues are able to recognize and reject pollen of the same S-genotype (incompatible pollen), or to accept growth of genetically different pollen tubes. Thus, the SI 
system protects plants from pollination with pollen carrying the same S-haplotype (McClure \& Franklin, 2006).

Two main systems of homomorphic SI comprise: gametophytic self-incompatibility (GSI) and sporophytic self-incompatibility (SSI). In GSI, the incompatibility phenotype is determined by the pollen haploid genome. The S-locus determines S-specificity of pollen recognition and rejection, so the pollen is rejected by the GSI system when the S-haplotype is the same as one of two S-alleles of the diploid pistil. This indicates that the S-locus products readily expressed in the pistil and pollen interact with each other and determine the compatibility or incompatibility of the emerging pollen tube.

In sporophytic SI, the pollen S-phenotype is determined by the diploid genome of the parental plant. Therefore, in GSI systems half-compatibility is shown between individuals that share one S-allele, while in SSI systems crosses are always fully compatible or fully incompatible (Allen \& Hiscock, 2008).

The SSI system has been reported in six families: Asteraceae, Berulaceae, Brassicaceae, Caryopgyllaceae, Convolvulaceae and Polemoniaceae. The molecular mechanism of the SSI has only been well characterized in Brassicaceae (see below) (Hiscock \& McInnis, 2003).

Studies of GSI species at the molecular level have identified two completely different SI mechanisms. One GSI mechanism, which is found in the Solanaceae, Rosaceae and Scrophulariaceae, has S-RNase as the pistil S-component and an F-box protein as the pollen S-component (see below). The second mechanism has been identified only in Papaver (poppy), where the interaction between male and female determinants transmits a cellular signal into the pollen tube, resulting in an influx of calcium cations. This influx interferes with the intracellular concentration gradient of calcium ions which exists inside the pollen tube, essential for its elongation (McClure \& Franklin-Tong, 2006; Zhang \& Xue, 2008).

\subsection{SSI mechanism of Brassicaceae}

In the Brassica species, two highly polymorphic self recognition proteins encoded in the Slocus have been identified: the S-locus receptor kinase (SRK), which is displayed at the surface of stigma epidermal cells and the S-locus cysteine-rich protein (SCR or SP11), which is expressed in the anther tapetum (i.e. sporophytically) and localized in the pollen coat (Schopfer et al., 1999; Suzuki et al., 2000; Takasaki et al., 2000). The SRK gene consists of seven exons, with the first exon encoding the signal peptide and extracellular domain, the second exon encoding the trans membrane domain and the remaining exons encoding the cytoplasmic kinase domain (Stein et al., 1996). All SCRs are small proteins of approximately 50 amino acids consisting of two exons: one encodes a signal peptide and the second one the mature SCR protein (Schopfer et al., 1999; Takayama 2001).

The interaction between the SRK and SCR proteins results in autophosphorylation of the intracellular kinase domain of the SRK and a signal is transmitted into the papilla cell of the stigma (Takayama et al., 2001). Another protein essential for the SI response is MLPK, a serine-threonine kinase, which is anchored to the plasma membrane from its intracellular side. The downstream cellular and molecular events, leading eventually to pollen inhibition, are poorly described (Murase et al., 2004). 


\subsection{S-RNase-based GSI}

The origin of the so-called S-RNase-based mechanism has been placed early in the eudicot evolution and is likely the most widespread SI mechanism operating among extant flowering plants (Richman et al., 1997; Allen \& Hiscock, 2008).

The S-RNase is a N-glycoprotein, consisting of five conservative regions and one or two hyper-variable (HV) sequence regions. The N-terminal signal peptide is short and absent in the mature protein, suggesting its secretory nature. The allelic polymorphism is clustered in the HV regions which are responsible for S-specificity. In Solanaceae, there are two such regions (HVA and HVB), while only one is in Rosaceae (RHV) (McClure \& Franklin-Tong, 2006; Zhang \& Xue, 2008). The sequence alignment of different S-RNases revealed large inter-specific diversity. The level of the S-locus polymorphism is similar to the histocompatibility system of Vertebrateae (Newbigin, 1996).

The S-RNases are expressed in the pistil and secreted to extracellular space. Then the SRNases penetrate pollen tubes where they interact with pollen proteins. Recent discoveries identified S-locus F-box (SFB or SLF) proteins as pollen components of the S-locus in all three families that utilize the S-RNase type of SI (Entani et al., 2003; Ikeda et al., 2004; Ushijiama et al., 2003, 2004; Sassa et al., 2007, 2010; De Franceschi et al., 2011). These proteins are components of the SCF (Skp1-Cullin1-F-box) complex (Qiao et al., 2004a, b).

The "protein degradation" model has explained the mechanism of S-haplotype-specific rejection of pollen tubes by S-RNase. The SLF proteins recognize non-self S-RNases and mediate their degradation by the ubiquitin-25S-proteasom system (Hua \& Kao, 2006; Hua et al., 2007). According to this hypothesis, each SLF allelic product mediates degradation of all SRNases except its own S-RNase. In incompatible pollen tubes, S-RNases exert cytotoxicity specifically by RNA degradation (Takayama \& Isogai, 2005; Hua \& Kao, 2006; Hua et al., 2007).

\section{Evolutionary characteristics of SI}

Besides studies on the molecular basis of self-recognition and rejection systems, high polymorphic S-locus might also provide a unique evolutionary and population history information. The evolutionary properties of self-incompatibility systems have been revealed through a fascinating interplay between empirical advances and theoretical developments since Wright (1939) suggested that the main evolution force driving the population genetics of SI species is negative frequency-dependent selection (Castric \& Vekemans, 2004).

\subsection{Frequency-dependent selection}

The self-incompatibility mechanisms put the pressure on individuals inside populations. All of them should be heterozygous at the S-locus and at least three S-alleles are required in the population because, if the number of alleles falls below three, the fertilization is blocked and the population is sentenced to extinction.

All S-alleles in the population are in the state of equilibrium with a similar frequency. If, for some reason, the allele frequency is disturbed, the population should establish a new equilibrium state during a few generiations, because of the negative frequency-dependent selection. This balancing selection consists in favoring rare S-haplotypes by increased 
opportunity for successful mating in the population (Newbigin, 1996; Richman \& Kohn, 2000; Charlesworth, 2006).

Theoretically, the new S-allele occurring in the population due to mutation, should successfully fertilize all the plants, so its frequency will increase until it reaches a new equilibrium state. The likelihood of successful fertilization is inversely proportional to the frequency of this allele in the population and the size of the particular S-haplotypes in the population can be quantified through the proportion $\mathrm{N}_{e} / \mathrm{n}_{e}$, where $\mathrm{N}_{\mathrm{e}}$ is the effective size of the whole population and $n_{e}$ is the effective number of alleles in the population (Vekemans \& Slatkin, 1994). Accordingly, S-locus has to be much more polymorphic than loci from a non-negative frequency-dependent selection and S-haplotypes are long-lived and resistant to the loss due to genetic drift. (Richman \& Kohn, 2000).

Observations from natural populations of species possessing GSI systems show that equal Sphenotypes frequencies are often, but not always, found. Meanwhile, in SSI populations, dominance relations make it more difficult to set expectations for the frequencies of different alleles, because these will depend on the dominance relations between all pairs of alleles (Richman \& Kohn, 2000; Bechsgaard et al., 2004). Theoretically, in equal frequencies of incompatibility types, the recessive alleles are expected to reach higher frequencies than dominant alleles, but they have shorter persistence times in the population (Schierup et al., 1997; Uyenoyama, 2000, Bechsgaard et al., 2004).

\subsection{Trans-specific evolution}

One of the fundamental questions about the volatility of S-alleles is the rate and the role of mutations. Based on the research on a large number of alleles observed, the mutation rate can be very high. However, the experimental studies have not confirmed such a high frequency of mutations in real populations (Newbigin, 1996). The relatively low mutation rate, coupled with the observation of an unexpectedly high polymorphism of the S-locus, lead to the conclusion that the S-allelic polymorphisms should be inherited from ancestors and the process of their formation and differentiation should begin before the currently existing species formation.

The negative selection which increases frequency of rare alleles also preserves polymorphism over a very long period of time. It has been estimated that genetic variability can be preserved at the S-locus for tens of millions of years, periods longer than the lifetime of a species. It means that S-haplotypes present in the related species have originated from a common ancestor (Ioerger, 1990; Takahata, 1990; Vekemans \& Slatkin, 1994; Richman \& Kohn, 2000; Wolko et al., 2010).

Due to the S-locus ancestral origin, the alleles from one species can be more internally divergent than alleles from different species but which originated from a common evolutional lineage. In the sequence-alignment analysis, the S-alleles from different species and genera can be clustered together indicating that the allelic lineages descended from a common ancestor (Richman et al., 1995; Sasala et al., 1996; Usijima et al., 1998; De Franceschi, 2011). In the Solanaceae, it has been estimated that majority of the observed Slocus polymorphisms arose before speciation from the common ancestor. This ancestor is believed to have occurred 35-45 million years ago (Ioerger et al., 1990; Richman at al., 1995, 1996a, 1996b; Igic et al., 2006; Paape et al., 2008; Kohn, 2008). 


\subsection{Long-term population history recorded in S-locus polymorphism}

The evolutional history has been recorded in S-alleles DNA sequences and can be demonstrated by the conservatism of the sequence that takes place between many different species or even between plant types, if the allele lineage is particularly old. The consequence of this is that the alleles occurring after the time of speciation must be descendents from one of the existing alleles. Therefore, the taxonomic spread of new alleles is much more limited than of the older alleles. Polymorphism that persists for tens of millions of years can be used to study the history of S-locus lineages, populations, species and genera.

The analysis of genetic variability of the S-locus in the population should include two main aspects. The first is the number of alleles in the population. This number grows in the population due to negative selection favoring rare alleles. However, an unlimited increase in the number of alleles driven by selection is inhibited by forces of genetic drift. At the equilibrium state, it is expected that the number of alleles in the population will increase proportionally to the population size, because the drift effect in large populations is weaker. Due to the fact that the number of alleles in a population reflects random changes in its size, this parameter exhibits a relatively recent event (the fluctuations in abundance) in the history of taxa.

The second aspect is the age of alleles which can be estimated by the sequence alignment of alleles from common species and genera. It is expected that this parameter would be much less variable than the number of alleles, because the selection mechanisms should prevent the disappearance of alleles. Some mutations in the gene sequence change allelic specificity, but differences of the entire accumulated sequence reflect the history of alleles over millions of years during the creation of species and varieties (Richman at al., 1995, 1996a, 1996b).

Estimation of the S-allele evolution rate can provide information about changes in the population size that took place in the distant past. The sequences of polymorphic alleles of a single species would reflect the history of the species. For example, if sequences have a large number of new alleles, it means that, at some point in the past, most of the older lineage alleles were lost, probably due to a sudden reduction in the population size ("bottleneck"). Therefore, the pedigree analysis of S-polymorphisms provides an opportunity for paleopopulation genetic studies (Takahata, 1990).

For example, in the total number of 93 S-allele sequences derived from the species of Physalis and Witheringia, all have fallen within only three lineages that predate the most recent common ancestor of these two genera (Richman at al., 1996a; Richman \& Kohn 1999, 2000; Lu, 2001; Stone \& Pierce, 2005). Therefore, the bottleneck of the S-locus clearly occurred prior to the most recent common ancestor of Physalis and Witheringia. Paape et al. (2008) identified Physalis and Witheringia S-allele lineage homologes in Iochromina. But Iochromina Slocus seems much more polymorphic and several lineages not represented in Physalis and Witheringia have been identified there. This means that the restriction in the S-locus number must have occurred after the most recent common ancestor of the group containing the Iochrominae and it has been estimated that the bottleneck must have occurred between 14 and 18 mya (Kohn, 2008; Paape et al., 2008).

However, the extreme type of bottleneck event is needed to explain the fact that only three ancient lineages are represented among the S-alleles of Physalis and Witheringia. A founder event involving perches as few as two individuals would seem the only likely way for such 
a restriction. But also the complete lack of further gene flow between other populations would be necessary because the subsequent gene flow would almost certainly introduce additional S-alleles (Kohn, 2008).

\subsection{Sheltered load-constrains S-alleles diversification}

Richman et al. (1996b), comparing the S-allele lineage diversity in Physalis crassifolia and Solanum carolinease, found that allele sequences from natural populations revealed a puzzling lack of correlation between the allele number and the number of trans-specific lineages in the genealogical analysis. P. crassifolia possesses 34 alleles residing in two lineages, while $S$. carolinense - 13 alleles scattered over multiple lineages within the Solanaceae. The lack of correlation between allele and lineage numbers is surprising because, as observed previously, differences in historical population size should lead to a positive correlation between the allele and lineage number (Richman et al, 1996a,b, Uyenoyama, 1997). In addition, genealogical studies exhibit a rapid diversification of the S-alleles near the base level of the genealogy with a subsequent deceleration of the diversification rate (Richman et al., 1996b).

The lack of correlation between the allele number and the divergence could be caused by differences in the fixation of mutations (Uyenoyama, 1997). The load of deleterious recessive mutations linked to S-locus accumulates due to two factors. First, the S-locus, by definition, is always expressed in heterozygous conditions, as pollen is rejected if it bears either allele held by the maternal plant. Second, the S-locus is in a non-recombining region of the genome (Uyenoyama, 1997; Coleman \& Kao, 1992).

Therefore, the deleterious recessive mutations that accumulate in the region surrounding the S-locus are even more sheltered from selection than unlinked deleterious recessives. As these mutations are sheltered by being kept in heterozygous state, the lineage-specific load is called 'sheltered load' (Uyenoyama, 1997; Stone, 2004; Jorge et al., 2009). The sheltered load could be expressed when a mutation leads to the formation of a new Sallele. The new allele is compatible with any other in the population leading to the formation of embryos containing both the new allele and its progenitor. Therefore, the regions surrounding the S-locus will be combined in homozygotes and the sheltered load has a chance to be expressed. If this load is sufficiently deleterious, selection will eliminate one of the two alleles in the population (Uyenoyama, 2003; Stone, 2004; Mena-Al1' et al., 2009). Thus, the fixation of new mutations and the diversification of the lineage should be blocked. Richman and Kohn (1999) found evidences that more divergent alleles were preserved when ecological factors reduced the effective population size and the number of S-alleles maintained.

Stone (2004) reported that crosses between distinct plants of $S$. carolinense sharing the same alleles at the S-locus led to dramatically high seed abortions, nearly equal to that found upon selfing. An excess of heterozygotes in the surviving progeny supports the hypothesis that these high abortion rates are caused by sheltered loads. Mena-Alı' et al. (2009) found evidence of variation in the magnitude of deleterious load among S-alleles in S. carolinense. These results suggest that sheltered loads might slow the fixation of weak (partially compatible) S-alleles in the population, thus adding to the maintenance of a mixed mating system rather than leading to the fixation of selfing alleles. 


\section{Origination of self-incompatibility specificities}

While the analysis of allele frequencies in populations can shed light on the fate of S-haplotypes, the major question is how new self-incompatibility specificities are generated and how male and female factors co-evolve to maintain their interaction?

Since pollen and pistil factors interact in the SI mechanism, mutations changing specificity of e.g. pollen, could result in a haplotype that is self-compatible. But the nonfunctional $S$-haplotypes are unlikely to be maintained along in population. They should be in the majority eliminated by inbreeding depression and selection against self-fertilization or, if they persist in a population, they should drive to extinction the functional haplotypes from which they arise (Chookajorn et al., 2004). Therefore, to form a new specificity, the mutation in both the female and the male components of the system should be required (Charlesworth, 2000).

\subsection{Formation of new S-specificities}

Attempts to explain how new specificities arise in two components of the SI system are faced with intriguing and difficult problems. One hypothesis proposes that the diversification process may devolop by means of intermediates and accumulation of polymorphism in the one gene that disrupts SI, followed by a compensatory mutation in the second gene that restores SI (Charlesworth, 2000; Uyenoyama \& Newbigin, 2000). Alternatively, the variability in both pollen and pistil components can be tolerated thanks to flexibility of the physical interaction of the factors. The mutual recognition can exist until, by chance, a new mutation produces protein exhibiting stronger affinity with some varieties of the corresponding S-allele. Then the natural selection drives the strengthening of the interactions (Chookajorn et al., 2004, Kemp \& Doughty, 2007; Naithani et al., 2007).

Since sequence polymorphism is necessary for the transitional stages of new S-allele formation under this model, variety of functional S-alleles in natural populations should provide opportunities to study this process. In Brassica oleracea, polymorphism withinspecificity and developmental stages of new specificities were described (Miege et al., 2001, Sato et al. 2006), whereas in Maloideae (Rosaceae) populations the observed within-specificity polymorphism was low (Uyenoyama et al., 2001; Raspe \& Kohn, 2007).

The rate of the formation of new specificities may depend on population conditions. It is known from studies on Solanaceae that the diversification rate of S-alleles increases following bottlenecks because of greater selection in the population below equilibrium of allele number (Richman, 2000; Paape et al., 2008; Miller et al., 2008). In the stable equilibrium state of populations, the negative frequency-dependent selection tends to preserve extreme polymorphism among alleles, but should have the opposite effect on the polymorphism within alleles, reducing it below levels of standard loci (Kohn, 2008).

One way of answering questions about S-haplotype creation could be the identification of amino-acid residues determining the specificity on the receptor and ligand. Slow progress has been achieved for the Brassicaceae SSI system, largely based on statistical analysis of sequences of the S-locus (Chookajorn et al., 2004; Kemp \& Doughty, 2007; Naithani et al., 2007). 


\subsection{Coevolution hypothesis}

The expectations for S-component genes are: tight linkage, high nucleotide polymorphism, long evolution history and evidence for balancing selection. The male and female factors should have long coevolution history because recombination events result in selfcompatibility. As expected, in the SSI system of Brassicaeae, SRK and SCR genes show high levels of synonymous and non-synonymous nucleotide polymorphism and the hypothesis of strict coevolution of linked pollen and pistil genes could not be rejected (Sato et al., 2002).

However, in S-RNase SI systems, several aspects of current findings differ very markedly from what would be expected if F-box and S-RNaze genes had the same evolutionary history (Kohn 2008). Surprisingly, sequences of particular F-box genes are more closely related to other F-box genes in this species, than to F-box genes of the S-locus lineage in other relative species. This contrasts sharply with S-RNase genes, where sequences show trans-species relationships (Sassa et al., 1996; Ushijama et al., 1998).

Additionally, levels of polymorphism of the F-box genes are surprisingly low in some taxa, while in others they seem to conform to expectations. In Prunus, SFBs show similar to SRNase levels of polymorphism and evidence of positive selection (Ikeda et al., 2004). The distances among Prunus S-RNase alleles and corresponding SLF alleles are correlated; however, genealogies of these genes do not strictly correspond, perhaps due to rare recombination events (Nunes et al., 2006).

In apple and pear (Rosaceae), multiple F-box genes within the S-locus region have been described. These genes were named S-locus F-Box Brothers (SFBB) (Sassa et al., 2007; De Franceschi et al., 2011). In European pear, for example, the S-locus contains no less than six SFBB members and exhibits much lower sequence diversity than their associated S-RNases and they show little or no evidence for positive selection. However, two of the genes show evidence of coevolution with S-RNases (De Franceschi et al., 2011). In Antirrhinum (Plantaginaceae), levels of divergence are at least an order of magnitude lower at the SLF locus than at the S-RNase locus (Wheeler \& Newbigin, 2007; Newbigin et al., 2008). This fact implies that the histories of the F-box genes and their S-RNases are markedly different. This surprising finding is far from the prevailing theory of the S-locus gene coevolution.

\subsection{Collaborative non-self recognition hypothesis}

Just recently, Kubo et al. (2010) shed new light on pollen specificity component problem, proposing a collaborative non-self recognition model for the S-RNase-based SI. In this mechanism, pollen S-specificity is conditioned by multiple types of SLF genes and every single F-box gene is able to recognize and mediate degradation of only a small subset of non-self S-RNases. Within an S-haplotype, products of the entire suite of SLF proteins collaborate in recognition and detoxification of different S-RNases (Kubo et al., 2010). In the previous model with a single F-box gene, the loss of SLF function would be lethal because such mutant would be incapable of detoxification of any S-RNases and would be incompatible with any haplotypes. According to collaborative recognition model, the loss of function or mutation of a single SLF would block pollination only of pistils carrying the SRNases recognized by the type of SLF affected by the mutation. Meanwhile, the mutation of the S-RNase gene causes escape detoxification from the existing repertoire of SLF proteins and blocks pollination by any pollen haplotypes (Kubo et la., 2010; Indriolo \& Goring, 2010). 
This model may suggest an evolution mechanism similar to pathogen-plant competition. It was previously proposed that SI systems evolved from pathogen defense mechanisms (Hodgkin et al., 1988; Elleman \& Dickinson, 1999) and that S-RNases that mediate GSI are related to RNases involved in defense against pathogens (Kao \& McCubbin, 1996; Galiana et al., 1997; Alen \& Hiscock, 2008).

So, the new allelic specificities may be generated by the process of competition between SRNases acting as plant-defense-like mechanism and pollen attempting to generate resistance-like response. The competition between stile and pollen components inducing polymorphism are also observed in real plant/pathogen interactions (Brunet \& Mundt, $2000 a, b)$. The first step of diversification would be the mutation in the S-RNase gene changing specificity and allowing new S-RNase to escape detoxification with the existing SLFs. It would cause the formation of a female-sterile and male-fertile phenotype. This new S-haplotype would spread across the population until it achieved the state of frequencydependent selection equilibrium. The increase of frequency of the new S-RNase allele in the population induces the selection pressure to generate pollen resistance. Generation of the new SLF specificity which allows pollen to inactivate the new S-RNase and to pollinate pistils would be advantageous by supplementing potential mating partners. This mechanism should be practically tested on wild populations by studying the temporary existence of hypothesized female sterility plants.

\section{Loss of SI}

Mutations that promote self-fertility occur in both sporophytic and gametophytic SI systems and disturb S-alleles themselves as well as genes that modify S-locus expression and genes involved in the downstream rejection pathway (Tsukamoto et al., 1999, 2003a, b; Mena-Alí \& Stephenson, 2007; Tao et al., 2007). The current models of SI maintain that the products of several unlinked genes are involved in the formation of multi-protein complex that cooperates in SI response (McClure \& Franklin-Tong, 2006). Because of the complexity of the SI response, there are many opportunities for mutations in genes involved in the rejection process to have a qualitative or quantitative effect on self-fertility (Good-Avila et al., 2008). Therefore, in many natural populations, SI is rather a quantitative trait due to the segregation of unlinked genes that modify the strength of SI (Levin, 1996; Good-Avila \& Stephenson, 2002).

The populations of the SI species with generic polymorphism for self-fertility have been found as populations in transition to SC. However, recently models with population stable state of equilibrium have been examined with mixed mating systems where genetic polymorphism for self-fertility may modify the SI and permit selfing in the same conditions (Vallejo-Marín \& Uyenoyama, 2004; Porcher \& Lande 2005).

The transition from SI to self-compatibility (SC) is viewed as one of the most frequent processes in plant evolution (Takebayashi \& Morrell, 2001, Igic et al., 2006). There are two advantages of self-pollination: reproductive assurance because selfed progeny is better than no progeny at all; lower energy cost to produce selfed seed. Consequently, the frequency of mutation that promotes self-fertilization should increase in a population unless this process is counterbalanced by an opposing selective pressure of inbreeding depression (reduction of the selfed progeny fitness as a result of the increase in homozygosity that exposes deleterious recessive alleles) (Good-Avila et al., 2008). 
Although mutations enhancing self-fertility are common in populations of SI species, most of them are eliminated by genetic drift or by purifying selection of inbreeding depression. On the other hand, these mutations are expected to increase in conditions of low numbers of S-alleles, low inbreeding depression (weak sheltered load) and limit of cross-pollen seed availability. In these conditions, mutations may become fixed resulting in the loss of SI.

When the SI mechanism is lost, polymorphism at the S-locus is switched to neutral selection and is expected to collapse in a few population (Kohn 2008). So, once polymorphism is lost, the SI system cannot be regained because, with fewer than three different alleles, all individuals are mutually incompatible. In addition, once the SI is lost, mutations in other genes of self-incompatibility are expected to accumulate (Stone, 2002; Igic et al., 2006, 2008).

If the SI is frequently and irreversibly lost during evolution, is self-incompatibility during this process vanishing in angiosperms? If it is not, than SI species must have a higher diversification rate (defined as the speciation rate minus the extinction rate) than SC taxa (Igic et al., 2004, 2008). The loss of SI mechanisms and transition to selfing should be a rather common evolutionary process. However, this pathway of evolution could often be a shortterm solution and one-way ticket to the evolutionary dead-end (Takebayashi \& Morrell, 2001; Kohn, 2008). Although selfing taxa usually show even greater levels of genetic diversification and would speciate faster than autcrossing taxa, the SI increases and preserves variation that might reduce the rate of total extinctions of taxa (Glémin et al., 2006; Kohn, 2008).

\section{Conclusions}

In this chapter, we tried to discuss issues concerning evolutional aspects of plant selfincompatibility. By mechanisms of frequency-dependent selection, self-incompatibility genes manage the population genetic diversity. It is a special case of Dawkins's "selfish gene", which, apart from natural selection, induces their spread in the population. This interesting phenomenon deserves a detailed analysis and verification of theoretical assumptions on the level of natural populations.

\section{Acknowledgment}

The research in the authors' laboratory is supported by grant No. 1413/B/P01/2009/37 from the Polish Ministry of Science and Higher Education.

\section{References}

Alen, M.A. \& Hiscock S.J. (2008) Enolution and phylogeny of self-incompatibility systems in angiosperms, In: Self-Incompatibility in Flowering Plants - Evolution, Diversity and Mechanisms. Franklin-Tong VE (Ed.), ISBN 978-3-540-68485-5Springer-Verlab, Berlin, Germany

Bechsgaard J., Bataillon T. \& Schierup M.H. (2004) Uneven segregation of sporophytic selfincompatibility S-lleles in Arabidopsis lyrata. J Evol Biol, Vol. 17, No. 3, (May 2004), pp. 554-561, ISSN 1010-061X 
Brunet, J. \& Mundt, C.C. (2000a). Disease, frequency-dependent selection, and genetic polymorphisms: experiments with stripe rust and wheat. Evolution, Vol. 54, No.2, (Apr 2000), pp. 406-415, ISSN 1936-6426

Brunet, J. \& Mundt, C.C. (2000b). Effects of competition on resistance gene polymorphism in a plant/pathogen system. Heredity, Vol 85, No 4, (Oct 2000), pp. 393-400, ISSN 0018-067X

Castric, V \& Vekemans, X (2004) Plant self-incompatibility in natural populations: A critical assessment of recent theoretical and empirical advances. Mol Ecol Vol. 13, No. 10, (Oct 2004), pp. 2873-2889, ISSN 0962-1083

Charlesworth,D. (2000) How can two-gene models of self incompatibility generate new specificities? Plant Cell, Vol. 12, No. 3, (Mar 2000), pp. 309-310, ISSN 1835-2693

Chookajorn, T., Kachroo, A., Ripoll, D.R., Clark, A.G. \& Nasrallah, J.B. (2004) Specificity determinants and diversification of the Brassica self-incompatibility pollen ligand. Proc Natl Acad Sci USA. Vol. 101, No.4, (Jan 2004), pp.911-917, ISSN 0027-8424

Charlesworth, D. (2006) Balancing selection and its effects on nearby genome regions. PLoS Genet Vol. 2, No. 4, (Apr 2006), pp. :379-384, ISSN 1553-7390

Coleman, C.E. \& Kao T-H. (1992). The flanking regions of two Petunia inflata S alleles are heterogeneous and contain repetitive sequences. Plant Mol. Biol., Vol. 18 No. 4 (Feb 1992), pp. 725-737, ISSN 0167-4412

Darwin, C.R.(1878) The effects of cross and self-fertilisation in the vegetable kingdom, 2nd edn. John Murry (Ed). London, UK

De Franceschi, P., Pierantoni, L., Dondini, L., Grandi, M., Sansavini, S. \& Sanzol J. (2011) Evaluation of candidate F-box genes for the pollen $S$ of gametophytic selfincompatibility in the Pyrinae (Rosaceae) on the basis of their phylogenomic context. Tree Genet. Genom. Vol. 7, No. 4 (Feb 2011), pp. 663-683, ISSN 1614-2942

Elleman, C.J. \& Dickinson, H.G. (1999) Commonalities between pollen/stigma and host/pathogen interactions: Calcium accumulation during stigmatic penetration by Brassica oleracea pollen tubes. Sex Plant Reprod Vol. 12, No. 3, (Jun 1999), pp. 194202, ISSN 0934-0882

Entani, T., Iwano, M., Shiba, H., Che, F.S., Isogai, A. \& Takayama, S. (2003) Comparative analysis of the self-incompatibility S-locus region of Prunus mume: identification of a pollen-expressed F-box gene with allelic diversity. Gene Cell, Vol. 8, No. 3, (Mar 2003), pp. 203-213. ISSN 1356-959

Galiana, E., Bonnet, P., Conrod, S., Keller, H., Panabières, F., Ponchet, M., Poupet, A. \& Ricci P. (1997) RNase activity prevents the growth of a fungal pathogen in tobacco leaves and increases upon induction of systemic acquired resistance with elicitin. Plant Physiol. Vol. 115, No. 4 (Dec 1997), pp. 1557-1567. ISSN 0032-0889

Glémin, S., Bazin, E. \& Charlesworth D. (2006) Impact of mating systems on patterns of sequence polymorphism in flowering plants. Proc $R$ Soc Biol Sci B, Vol. 273, No 1604, (Jun 2006), pp. 3011-3019. eISSN 1471-2954

Good-Avila, S.V. \& Stephenson, A. (2002) The inheritance of modifiers conferring selffertility in Campanula rapunculoides L. (Campanulaceae). Evolution Vol. 56, No. 2, (Feb 2002), pp. 263-272, ISSN 0014-3820

Good-Avila, S.V., Mena-Ali,J.I. \& Stephenson, S.G. (2008) Genetic and environmental causes and evolutionary consequences of variations in self-fertility in self incompatible species. In: Self-Incompatibility in Flowering Plants - Evolution, Diversity and 
Mechanisms. Franklin-Tong VE (Ed.), ISBN 978-3-540-68485-5Springer-Verlab, Berlin, Germany

Hiscock, S.J. \& McInnis, S.M. (2003) The diversity of self-incompatibility systems in flowering plants. Plant Biol.Vol 5, No. 1, (Jan 2003), pp. 23-32. ISSN 1435-8603

Hodgkin, T., Lyon, G.D. \& Dickinson HG (1988) Recognition in Flowering Plants: A Comparison of the Brassica Self-Incompatibility system and plant pathogen interactions. New Phytol, Vol. 110, No. 4 (Dec 1988), pp. 557-569, ISSN 0028646X

Hua, Z. \& Kao, T.-h. (2006) Identification and characterization of components of a putative Petunia S-Locus F-box-containing E3 ligase complex involved in S-RNase-based self-incompatibility. Plant Cell Vol. 18, No.10, (Oct 2006), pp. 2531-2553, ISSN 18352693

Hua, Z.H., Meng, X.Y., \& Kao, T.H. (2007) Comparison of Petunia inflata S-locus F-box protein (Pi SLF) with Pi SLF-like proteins reveals its unique function in S-RNasebased self-incompatibility. Plant Cell, Vol. 19, No. 11 (Nov 2007), pp. 3593-3609, ISSN 1835-2693

Igic, B., Bohs, L. \& Kohn, J.R. (2004) Historical inferences from the self-incompatibility locus. New Phytol, Vol. 161, No. 1, ( Jan., 2004), pp. 97-105, ISSN 0028646X

Igic, B., Bohs, L. \& Kohn, J.R. (2006) Ancient polymorphism reveals unidirectional breeding system shifts. Proc Natl Acad Sci USA, Vol. 103, No. 5, (Jan 2006), pp.1359-1363, ISSN 0027-8424

Igic, B., Lande, R. \& Kohn, J.R. (2008) Loss of self-incompatibility and its evolutionary consequences. Int J Plant Sci Vol. 169, No. 1, (Jan 2008) pp. 93-104, ISSN 1058-5893

Ikeda, K., Igic, B., Ushijima, K., Yamane, H., Hauck, N.R., Nakano, R., Sassa, H., Iezzoni, A.F., Kohn, J.R. \& Tao, R. (2004) Primary structural features of the S-haplotypespecific F-box protein, SFB, in Prunus. Sex Plant Reprod Vol. 16, No. 5, (Dec 2004), pp. 235-243. ISSN 0934-0882

Indriolo, E. \& Goring, D.R. (2010) Plant science. Pollen gets more complex. Science, Vol. 330, No. 6005, (Nov 2010), pp. 767-768, ISSN 0036-8075

Ioerger, T.R., Clark, A.G. \& Kao, T.H. (1990) Polymorphism at the self-incompatibility locus in Solanaceae predates speciation. Proc Natl Acad Sci USA, Vol. 87, No. 24, (Dec 1990), pp.9732-9735, ISSN 0027-8424

Kao, T.H. \& McCubbin, A.G. (1996) How flowering plants discriminate between self and non-self pollen to prevent inbreeding. Proc Natl Acad Sci USA Vol. 93, No. 22, (Oct 1996), pp. 12059-12065. ISSN 0027-8424

Kemp, B.P. \& Doughty, J. (2007) S cysteine-rich (SCR) binding domain analysis of the Brassica selfincompatibility S-locus receptor kinase. New Phytol, Vol. 175, No. 4, (Jun 2007), pp. 619-629, ISSN 0028646X

Kohn, J.R. (2008) What genealogies of S-alelles tell us. In: Self-Incompatibility in Flowering Plants - Evolution, Diversity and Mechanisms. Franklin-Tong VE (Ed.), ISBN 978-3540-68485-5Springer-Verlab, Berlin, Germany

Kubo, K., Entani, T., Takara, A., Wang, N., Fields, A.M., Hua, Z., Toyoda, M., Kawashima, S., Ando, T., Isogai, A., Kao, T.H. \& Takayama, S. (2010) Collaborative non-self recognition system in S-RNase-based self-incompatibility. Science. Vol. 330, No. 6005, (Nov 2010), pp 796-799, ISSN 0036-8075 
Lawrence, M.J. (2000) Population genetics of the homomorphic self-incompatibility polymorphisms in flowering plants. Ann Bot, Vol. 85 No. suppl. A (Jan 2000), pp. 221-226, ISSN 0305-7364

Levin, D.A. (1996) The evolutionary significance of pseudo self-fertility. Am Nat, Vol. 148, No. 2 (Aug 1996), pp. 321-332, ISSN 00030147

Lu, Y. (2001) Roles of lineage sorting and phylogenetic relationship in the genetic diversity at the self-incompatibility locus of Solanaceae. Heredity Roles of lineage sorting and phylogenetic relationship in the genetic diversity at the self-incompatibility locus of Solanaceae. Heredity, Vol. 86, No.2 (Feb 2001), pp. 195-205, ISSN 0018-067X

McClure, B. \& Franklin-Tong, V. (2006) Gametophytic self-incompatibility: understanding the cellular mechanisms involved in "self" pollen tube inhibition. Planta Vol. 224, No. 22, (Jun 2006), pp. 233-245, ISSN 0032-0935

Mena-Alí, J.I. \& Stephenson, A.G. (2007) Segregation analyses of partial self-incompatibility in self and cross progeny of Solanum carolinense reveal a leaky S-allele. Genetics, Vol. 177, No. 1, (Sept 2007), pp. 501-510, ISSN 0016-6731

Mena-Alí, J.I., Keser, L.H. \& Stephenson, A.G. (2009) The effect of sheltered load on reproduction in Solanum carolinense, a species with variable self-incompatibility. Sex Plant Reprod Vol. 22, No. 2, (Jun 2009), pp. 63-71, ISSN 0934-0882

Miege, C., Ruffio-Chable, V., Schierup, M.H., Cabrillac, D., Dumas, C., Gaude, T. \& Cock, J.M. (2001) Intrahaplotype polymorphism at the Brassica S-locus. Genetics Vol. 159 No. 2. (Oct 2001), pp. 811-822, ISSN 0016-6731

Miller, J.S., Levin, R.A. \& Feliciano, N.M. (2008) A tale of two continents: Baker's rule and the maintenance of self-incompatibility in Lycium (Solanaceae). Evolution, Vol. 62, No. 5 (May 2008), pp.1052-1065, ISSN 0014-3820

Murase, K., Shiba, H., Iwano, M., Che, F.S., Watanabe, M., Isogai, A., \& Takayama S. (2004). A membrane-anchored protein kinase involved in Brassica self-incompatibility signaling. Science Vol. 303, No. 5663, (Mar 2004), pp.1516-1519, ISSN 0036-8075

Naithani, S., Chookajorn, T., Ripoll, D.R. \& Nasrallah, J.B. (2007) Structural modules for receptor dimerization in the S-locus receptor kinase extracellular domain. Proc Natl Acad Sci USA Vol. 104, No. 29, (Jul 2007), pp. 12211-12216, ISSN 0027-8424

Newbigin, E. (1996) The evolution of self-incompatibility: a molecular voyeur's perspective. Sex Plant Reprod, Vol. 9, No. 6, (Aug 1996) pp. 357-361. ISSN 0934-0882

Newbigin, E., Paape, T. \& Kohn, J.R. (2008) RNase-Based Self-Incompatibility: Puzzled by Pollen Sw . Plant Cell, Vol. 20, No. 9, (Sept 2008), pp. 2286-2292. ISSN 1835-2693

Nunes, M.D.S., Santos, R.A.M., Ferreira, S.M., Viera, J. \& Viera, C.P. (2006) Variability patterns and positively selected sites at the gametophytic self incompatibility pollen SFB gene in a wild self-incompatible Prunus spinosa (Rosaceae) population. New Phytol Vol. 172, No. 3, (Jul 2006), pp. 577-587, ISSN 0028-646X

Paape, T., Igic, B., Smith, S.D., Olmstead, R., Bohs, L., Kohn, J.R. (2008) A 15-million-year-old genetic bottleneck. Mol Biol Evol,Vol. 25, No. 4, (Jan 2008), pp. 655-663, ISSN 07374038

Porcher, E. \& Lande, R. (2005) Loss of gametophytic self-incompatibility with evolution of inbreeding depression. Evolution, Vol. 59, No. 1, (Jan 2005), pp. 46-60, ISSN 00143820

Qiao, H., Wang, H., Zhao, L., Zhou, J., Huang, J., Zhang, Y. \& Xue, Y. (2004a). The F-box protein AhSLF-S2 physically interacts with S-RNases that may be inhibited by the 
ubiquitin/26S proteasome pathway of protein degradation during compatible pollination in Antirrhinum. Plant Cell Vol. 16, No. 3, (Mar 2004), pp. 582-595, ISSN 1835-2693

Qiao, H., Wang, F., Zhao, L., Zhou, J., Lai, Z., Zhang, Y., Robbins, T.P. \& Xue, Y. (2004b). The F-box protein AhSLF-S2 controls the pollen function of S-RNase-based selfincompatibility. Plant Cell, Vol. 16, No. 3, (Mar 2004), pp. 2307-2322, ISSN 18352693

Raspé, O. \& Kohn, J.R. (2007) Population structure at the S-locus of Sorbus aucuparia. Mol Ecol, Vol 16, No. 6, (March 2007), pp.1315-1325, ISSN 0962-1083

Richman, A.D., Kao, Th., Schaeffer, S.W. \& Uyenoyama, M.K. (1995) S-allele sequence diversity in natural populations of Solanum carolinense (Horsenettle). Heredity, Vol. 75, No. 4, (Oct 1995), pp. 405-415, ISSN 0018-067X

Richman, A.D., Uyenoyama, M.K. \& Kohn, J.R. (1996a) S-allele diversity in a natural population of ground cherry Physalis crassifolia (Solanaceae) assessed by RT-PCR. Heredity, Vol 76, No. 5 (May 1996), pp. 497-505, ISSN 0018-067X

Richman, A.D., Uyenoyama, M.K. \& Kohn, J.R. (1996b) Contrasting patterns of allelic diversity and gene genealogy at the self-incompatibility locus in two species of Solanaceae. Science, Vol. 273, No. 5279 (Aug 1996), pp. 1212-1216, ISSN 0036-8075

Richman, A.D., Broothaerts, W. \& Kohn, J.R. (1997) Self-incompatibility RNases from three plant families: homology or convergence? Am J Bot, Vol 84, No. 7, (Jul 1997), pp. 912-917, ISSN 1537-2197

Richman, A.D. \& Kohn, J.R. (1999) Self-incompatibility alleles from Physalis: Implications for historical inference from balanced genetic polymorphisms. Proc Natl Acad Sci USA, Vol. 96, No 1, (Jan 1999), pp. 168-172, ISSN 0027-8424

Richman, A.D. (2000) Evolution of balanced genetic polymorphism. Mol Ecol, Vol. 9, No. 12, (Dec 2000), pp. 1953-1963, ISSN 0962-1083

Richman, A.D. \& Kohn J.R. (2000) Evolutonary genetics of self-incompatibility in the Solanaceae. Plant Mol Biol, Vol. 42, No. 1, (Jan 2000), pp. 169-179, ISSN 0167-4412

Sassa, H., Nishio, T., Kowyama, Y., Hirano, H., Koba, T. \& Ikehashi, H. (1996) Selfincompatibility (S) alleles of the Rosaceae encode members of a distinct class of the T2/S ribonuclease superfamily. Mol Gen Genet, Vol. 250, No. 1-2 (Aug 1996), pp. 547-557, ISSN 0026-8925

Sassa, H., Kakui, H., Miyamoto, M., Suzuki, Y., Hanada, T., Ushijima, K., Kusaba, M., Hirano, H. \& Koba, T. (2007) S-locus F-box brothers: multiple and pollen-specific Fbox genes with S-haplotypespecific polymorphisms in apple and Japanese pear. Genetics, Vol. 175, No. 4, (Apr 2007), pp.1869-1881, ISSN 0016-6731

Sato, K., Nishio, T., Kimura, R., Kusaba, M., Suzuki, T., Hatakeyama, K., Ockendon, D.J., Satta, Y. (2002) Coevolution of the S-locus genes SRK, SLG and SP11/SCR in Brassica oleracea and B. rapa. Genetics, Vol. 162, No. 2, (Oct 2002), pp. 931-940, ISSN 0016-6731

Sato, Y., Sato, K. \& Nishio, T. (2006) Interspecific pairs of class II S-haplotypes having different recognition specificities between Brassica oleraceae and Brassica rapa. Plant Cell Physiol, Vol. 47, No. 3, (Mar 2006), pp, 340-345. ISSN 0032-0781

Schierup, M.H., Vekemans, X. \& Christiansen, F.B. (1997) Evolutionary dynamics of sporophytic self-incompatibility alleles in plants. Genetics, Vol. 147, No. 2, (Oct 1997), pp. 835-846, ISSN 0016-6731 
Schopfer, C.R., Nasrallah, M.E. \& Nasrallah, J.B. (1999) The male determinant of selfincompatibility in Brassica. Science, Vol. 286, No. 5445, (Nov 1999), pp. 1697-700, ISSN 0036-8075

Stein, J., Dixit, R., Nasrallah, M.E. \& Nasrallah, JB (1996) SRK, the stigma-specific S-locus receptor kinase of Brassica, is targeted to the plasma membrane in transgenic tobacco. Plant Cell, Vol. 8, No. 3, (Mar 1996), pp. 429-445, ISSN 1835-2693

Stone, J.L. (2002) Molecular mechanisms underlying the breakdown of gametophytic selfincompatibility. Quart Rev Biol, Vol. 77, No. 1, (Mar 2002), pp. 17-32, 0033-5770

Stone, J.L. (2004) Sheltered load associated with S-alleles in Solanum carolinense. Heredity, Vol. 92, No. 4, (Apr 2004), pp. 335-42, ISSN 0018-067X

Stone, J.L. \& Pierce, S.E. (2005) Rapid recent radiation of S-RNase lineages in Witheringia solanacea (Solanaceae). Heredity, Vol. 94, No. 5, (May 2005), pp. 547-555, ISSN 0018067X

Suzuki, T., Kusaba, M., Matsushita, M., Okazaki, K. \& Nishio, T. (2000) Characterization of Brassica S-haplotypes lacking S-locus glycoprotein. FEBS Lett, Vol. 482, No. 1-2, (Sept 2000), pp. 102-108, ISSN 0014-5793

Takahata, N. (1990) A simple genealogical structure of strongly balanced allelic lines and trans-species evolution of polymorphism. Proc Natl Acad Sci USA, Vol. 87, No. 7, (Apr 1990), pp. 2419-2423, ISSN 0027-8424

Takasaki, T., Hatakeyama, K., Suzuki, G., Watanabe, M., Isogai, A. \& Hinata, K. (2000) The S receptor kinase determines self-incompatibility in Brassica stigma. Nature, Vol. 403, No. 6772, (Feb 2000), pp. 913-916. ISSN 0028-0836

Takayama, S.H., Shimosato, H., Shiba, M., Funato, F-E., Che, M., Watanabe, M., Iwano, M. \& Isogai, A. (2001). Direct ligand-receptor complex interaction controls Brassica selfincompatibility. Nature, Vol. 413, No. 6855, (Oct 2001), pp. 534-538, ISSN 0028-0836

Takayama, S. \& Isogai, A. (2005) Self-incompatibility in plants. Annu Rev Plant Biol,Vol. 56, (Jun 2005), pp. 467-489, ISSN 1543-5008

Takebayashi, N. \& Morrell, P.L. (2001) Is self-fertilization an evolutionary dead end? Revisiting an old hypothesis with genetic theories and a macroevolutionary approach. Am J Bot, Vol. 88, No. 7, (Jul 2001), pp. 1143-1150, ISSN 0002-9122

Tao, R., Watari, A., Hanada, T., Habu, T., Yaegaki, H., Yamaguchi, M. \& Yamane, H. (2007) Self-compatible peach (Prunus persica) has mutant versions of the S-haplotypes found in self-incompatible Prunus species. Plant Mol Biol, Vol. 63, No. 1, (Jan 2007), pp. 109-123, ISSN 0167-4412

Tsukamoto, T., Ando, T., Kokubun, H., Watanabe, H., Masada, M., Zhu, X., Marchesi, E. \& Kao, T-H. (1999) Breakdown of self-incompatibility in a natural population of Petunia axillaris (Solanaceae) in Uruguay containing both self-incompatible and selfcompatible plants. Sex Plant Reprod, Vol. 12. No. 1, (Jan 1999), pp. 6-13, ISSN 09340882

Tsukamoto, T., Ando, T., Takahashi, K., Omori, T., Watanabe, H., Kokubun, H., Marchesi, E. \& Kao, T-H. (2003a) Breakdown of self-incompatibility in a natural population of Petunia axillaris caused by loss of pollen function. Plant Physiol Vol, 131, No. 4, (Apr 2003), pp. 1903-1912, ISSN 0032-0889

Tsukamoto, T., Ando, T., Kokubun, H., Watanabe, H., Sato, T., Masada, M., Marchesi, E. \& Kao, T-H. (2003b) Breakdown of self-incompatibility in a natural population of Petunia axillaris caused by a modifier locus that suppresses the expression of an S- 
RNase gene. Sex Plant Reprod Vol. 15, No. 5, (May 2003), pp. 255-263, ISSN 09340882

Ushijima, K., Sassa, H., Tao, R., Yamane, H., Dandekar, A.M., Gradziel, T.M. \& Hirano H. (1998) Cloning and characterization of cDNAs encoding S-RNases in almond (Prunus dulcis): primary structural features and sequence diversity of the S-RNases in Rosaceae. Mol Gen Genet, Vol. 260, No. 2-3, (Nov 1998), pp.261-268, ISSN 00268925

Ushijima, K., Sassa, H., Dandekar, A.M., Gradziel, T.M., Tao, R. \& Hirano, H. (2003) Structural and transcriptional analysis of the self-incompatibility locus of almond: identification of a pollen expressed F-box gene with haplotype-specific polymorphism. Plant Cell, Vol. 15, No. 3, (Mar 2003), pp. 771-781, ISSN 1835-2693

Ushijima, K., Yamane, H, Watari A, Kakehi E, Ikeda K, Hauck NR, Iezzoni A, Tao R (2004) The S-haplotype-specific F-box protein gene, SFB, is defective in self-compatible haplotypes of Prunus avium and P. mume. Plant J, Vol. 39, No. 4, (Aug 2004), pp. 573-586. ISSN 0960-7412

Uyenoyama, M.K., (1997). Genealogical structure among alleles regulating selfincompatibility in natural populations of flowering plants. Genetics, Vol. 147, No. 4, (Aug 2004), pp. 1389-1400, ISSN 0016-6731

Uyenoyama, M.K. (2000) Evolutionary dynamics of self-incompatibility alleles in Brassica. Genetics, Vol. 156, No. 1, (Sep 2000), pp. 351-359, ISSN 0016-6731

Uyenoyama, M.K. \& Newbigin, E. (2000) Evolutionary dynamics of dual-specificity selfincompatibility alleles. Plant Cell Vol. 12, No. 3, (Mar 2000), pp. 310-312, ISSN 18352693

Uyenoyama, M.K., Zhang, Y. \& Newbigin, E. (2001) On the origin of selfincompatibility haplotypes: Transition through self-compatible intermediates. Genetics Vol. 157, No. 4, (Apr 2001), pp. 1805-1817, ISSN 0016-6731

Uyenoyama, M.K. (2003). Genealogy-dependent variation in viability among selfincompatibility genotypes. Theor Popul Biol, Vol. 63, No. 4, (Jun 2003), pp. 281-293 ISSN 0040-5809

Vallejo-Marín, M. \& Uyenoyama, M.K (2004) On the evolutionary costs of selfincompatibility: Incomplete reproductive compensation due to pollen limitation. Evolution Vol. 58, No. 9, (Sep 2004), pp. 1924-1935, ISSN 0014-3820

Vekemans, X. \& Slatkin, M. (1994) Gene and allelic genealogies at a gametophytic selfincompatibility locus. Genetics, Vol. 137, No. 4, (Aug 1994), pp. 1157-1165, ISSN 0016-6731

Wheeler, D. \& Newbigin, E. (2007) Expression of 10 S-class SLF-like sequences in Nicotiana alata pollen and its implications for understanding the pollen factor of the $S$-locus. Genetics, Vol. 177, No. 4, (Dec 2007), pp. 1-10. ISSN 0016-6731

Wolko, Ł., Antkowiak, W., Sips M. \& Słomski, R. (2010) Self-incompatibility alleles in Polish wild pear (Pyrus pyraster (L.) Burgsd.): a preliminary analysis. J Appl Gene, Vol. 51, No. 1 ( Jan 2010), pp 33-35, ISSN 1234-1983

Wright, S. (1939) The distribution of self-sterility alleles in population. Genetics Vol. 24, No. 4, (Jun 1939), pp. 538-552, ISSN 0016-6731

Zhang, Y. \& Xue, Y. (2008) Molecular biology of S-RNase-based self-incompatibility. In: SelfIncompatibility in Flowering Plants - Evolution, Diversity and Mechanisms. FranklinTong VE (Ed.), ISBN 978-3-540-68485-5Springer-Verlab, Berlin, Germany 


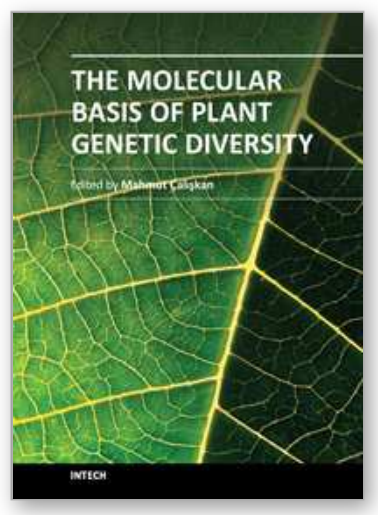

\author{
The Molecular Basis of Plant Genetic Diversity \\ Edited by Prof. Mahmut Caliskan
}

ISBN 978-953-51-0157-4

Hard cover, 374 pages

Publisher InTech

Published online 30, March, 2012

Published in print edition March, 2012

The Molecular Basis of Plant Genetic Diversity presents chapters revealing the magnitude of genetic variations existing in plant populations. Natural populations contain a considerable genetic variability which provides a genomic flexibility that can be used as a raw material for adaptation to changing environmental conditions. The analysis of genetic diversity provides information about allelic variation at a given locus. The increasing availability of PCR-based molecular markers allows the detailed analyses and evaluation of genetic diversity in plants and also, the detection of genes influencing economically important traits. The purpose of the book is to provide a glimpse into the dynamic process of genetic variation by presenting the thoughts of scientists who are engaged in the generation of new ideas and techniques employed for the assessment of genetic diversity, often from very different perspectives. The book should prove useful to students, researchers, and experts in the area of conservation biology, genetic diversity, and molecular biology.

\title{
How to reference
}

In order to correctly reference this scholarly work, feel free to copy and paste the following:

Łukasz Wolko and Ryszard Słomski (2012). Plant Self-Incompatibility: Or, Self-Induction of Population Genetic Diversity, The Molecular Basis of Plant Genetic Diversity, Prof. Mahmut Caliskan (Ed.), ISBN: 978-953-510157-4, InTech, Available from: http://www.intechopen.com/books/the-molecular-basis-of-plant-geneticdiversity/plant-self-incompatibility-or-self-induction-of-population-genetic-diversity

\section{INTECH}

open science | open minds

\section{InTech Europe}

University Campus STeP Ri

Slavka Krautzeka 83/A

51000 Rijeka, Croatia

Phone: +385 (51) 770447

Fax: +385 (51) 686166

www.intechopen.com

\section{InTech China}

Unit 405, Office Block, Hotel Equatorial Shanghai

No.65, Yan An Road (West), Shanghai, 200040, China

中国上海市延安西路65号上海国际贵都大饭店办公楼 405 单元

Phone: +86-21-62489820

Fax: $+86-21-62489821$ 
(C) 2012 The Author(s). Licensee IntechOpen. This is an open access article distributed under the terms of the Creative Commons Attribution 3.0 License, which permits unrestricted use, distribution, and reproduction in any medium, provided the original work is properly cited. 